\title{
GOETHE'S “GOETZ VON BERLICHINGEN" AND LILLO'S "HISTORY OF GEORGE BARNWELL"
}

In Goetz von Berlichingen we have a number of characters that are not found in the autobiography of the old knight, the most important among them being Adelheid, Weislingen, and Maria, Goetz's sister. Weislingen's affections are divided between Maria and Adelheid, until finally Adelheid wins him over completely-a situation which was a favorite one with Goethe and other poets of the Storm and Stress. It has been pointed out by Minor $^{1}$ and Weissenfels ${ }^{2}$ that Goetz von Berlichingen is not merely a historical drama, but contains elements of the bourgeois drama. These elements may be seen clearly in the scenes where Adelheid, Weislingen, and Maria appear. In the following I wish to show that the three characters have much in common with certain characters in Lillo's well-known play, The London Merchant; or, The History of George Barnwell, and that some of the scenes present striking parallels.

Lillo's tragedy ${ }^{3}$, which appeared in London in 1731, occupies an important place in the history of the German drama, small though its influence has been upon English literature. Shortly after its appearance the play was translated into French, and became known in Germany through the French translation, as was the case with so many English works curing the first part of the eighteenth century. Later two German editions appeared which had been translated directly from the original." In Goethe's youth George Barnwell was one of the most popular plays on the German stage. When speaking of his father's aversion to the theater and his own fondness of it, Goethe relates (Dichtung und

1 Schiller, Vol. II, p. 121.

2 Goethe im Sturm und Drang (1894), Vol. I, p. 371.

3 The edition of Lillo's works before me is in two volumes (London, 1775). The History of George Barnwell is in the first volume.

4 Cf. L. Hoffmann, George Lillo (Diss. Marburg, 1888), pp. 18f.; Goedeke, Grundriss, Vol. III, p. 369.

493]

[Modern Philologx, April, 1906 
Wahrheit, Book III), that he and his father had many disputes concerning the moral value of the stage. "Die schönen Beispiele von bestraften Vergehungen, 'Miss Sara Sampson' und 'Der Kaufmann von London,' wurden sehr lebhaft von mir hervorgehoben." Goethe mentions the play again in a letter to his sister from Leipzig (Goethe-Jahrbuch, Vol. VII, p. 13; Stein, Goethe-Briefe, Vol. I, p. 25); "Dein Leibstück den Kaufmann von London habe ich spielen sehen. Beym grössten Teil des Stückes gegähnt, aber beym Ende geweint" (1765). It would seem from this letter that Goethe had never seen a performance of the London Merchant before. The passage in Dichtung und Wahrheit, however, which refers to the first Frankfort period, gives us the impression that he had seen the play. We may have here another case where Goethe's memory failed him in a minor point when writing his autobiography. It is not unreasonable, however, to assume that, though Goethe had not seen the play on the stage previous to the Leipzig performance, he was familiar with the plot and could use it as an argument for the moral value of the stage. At any rate, the fact is clearly established that at least the second part of Lillo's tragedy made a deep impression upon the young poet.

The three characters in Lillo's play that are to be compared with Weislingen, Adelheid, and Maria in Goetz von Berlichingen are George Barnwell, Millwood, and Maria, the daughter of the merchant Thorowgood. It must be borne in mind, however, that Lillo's artistic powers are very limited; his characters often lack psychological truth, consistency, and vitality; he is often compelled to state in so many words what Goethe expresses through indirect characterization. George Barnwell is an inexperienced, well-intentioned youth, without strength of character, who falls a prey to the wiles of Millwood and to his own amorous disposition, but not without a struggle. If his character is not so convincing as that of Weislingen, it is the fault of the poet who has failed to motivate sufficiently his moral ruin. Weislingen, though not as young and inexperienced as Barnwell, has essentially the same traits; he is well intentioned, weak, passionate. Trueman characterizes his friend Barnwell as follows (Act III, sc. 2) : "an open, generous manliness of temper; his manners easy, unaffected and 
engaging." The words might be applied to Weislingen. Millwood is not the common harlot that she is generally supposed to be. She may seem so perhaps at the beginning of the play, but later she rises far above the ordinary courtesan. She approaches the type of the Machtweib who scorns social conventions and human laws, because they interfere with her own nature, with the development of her individuality. She is thoroughly selfish, like Adelheid; she desires wealth, as Adelheid desires power and position. Barnwell is completely in her power, and when he has done for her what he could, she tries to get rid of him, as Adelheid rids herself of Weislingen. Thorowgood's daughter Maria and Goetz's sister Maria have less in common than either of the other pairs. It is not impossible that Goethe's choice of the name may be due to perhaps unconscious recollection. The name does not occur in Goetz's autobiography. Still, the use of such a common name is of little significance. Maria is in a melancholy state of mind, owing to her secret love for Barnwell. Her love, however, does not make her unmindful of her reputation. When she advances her own money to cover up Barnwell's embezzlement, she anxiously asks Trueman whether she was doing anything unbecoming her sex and character. "A virgin's fame is sullied by suspicion's lightest breath" (Act III, sc. 1). A similar state of mind is revealed by Goetz's sister in her conversation with her lover, Weislingen.

Let us now take up different scenes in the two plays. In the second scene of the first act of the London Merchant we find Millwood at her toilet with Lucy, her maid. Millwood relates that she has met a young man and has asked him to call.

Lucy: Is he handsome? Millwood: Ay, ay, the stripling is well made, and has a good face .... Lucy: Innocent, handsome and about eighteen!-you'll be vastly happy.-Why, if you manage well, you may keep him to yourself these two or three years.

In Goetz we have a similar scene between Adelheid and her maid $(Z u$ Bamberg $) .{ }^{1}$ Here it is the maid who praises Weislingen's handsome appearance, as she has seen him first. "Das wäre ein

1 Der junge Goethe (Vol. II, pp. 89 f.). The passages are all taken from the first version of the play, though I have retained the more familiar form Goetz. 
Herr für euch," she concludes. Weissenfels (Goethe im Sturm und Drang, p. 513) compares this scene in Goetz with the conversation between Marwood and Hannah in Lessing's Miss Sara Sampson (Act II, sc. 1,2); but the characteristic remark of the maid is lacking, as Marwood and Mellefont are old acquaintances, and there is no praise of the good looks of the young man. In the second scene between Adelheid and her maid (D. $j$. Goethe, II, 94) the latter says in reference to Weislingen: "Ihr habt sein Herz geangelt und wenn er sich losreissen will verblutet er." Then she leaves the room, and Weislingen enters. In the scene between Millwood and Lucy (I, 2) Millwood says: "he has swallowed the bait, promised to come and this is the time I expect him." At this moment Barnwell knocks, and Lucy leaves the room to usher in Barnwell. The important point is not so much the similarity in the figure of speech ${ }^{1}$ as in the dramatic technique. In the short interval between Lucy's exit and Barnwell's entrance Millwood soliloquizes about the best way of receiving Barnwell:

Less affairs must give way to those of more consequence; and I am strangely mistaken if this does not prove of great importance to me and him too before I have done with him.-Now after what manner shall I receive him? let me consider-what manner of person am I to receive? he is young, innocent, and bashful: therefore I must take care not to put him out of countenance at first.-But then if I have any skill in physiognomy, he is amorous; and, with a little assistance, we'll soon get the better of his modesty. - I'll e'en trust to nature, who does wonders in these matters. - If to seem what is not, in order to be the better lik'd for what one really is; if to speak one thing, and mean the direct contrary, be art in a woman-I know nothing of nature.

If we except the reference to Barnwell's youth and bashfulness, the words might have been spoken by Adelheid; they fully agree with her character and the whole manner in which she gains Weislingen's confidence and affection. Lillo has to resort to words; Goethe makes his persons act. Liebetraut's words to Adelheid ( $D . j$. G., II, 90), "Ihr wisst nur zu gut wie man Männer fängt," apply equally well to Millwood.

In her conversation with Barnwell, Millwood tries to persuade him not to return to his master at once, but to stay with her. She

1 The same figure is used at great length in Antony and Cleopatra, II, 5. 
is aiming at his loyalty to his master, at his honesty and integrity. Similarly Adelheid persuades Weislingen to stay and to renounce his loyalty to his friend Goetz. Attention has often been called to the strange fact that Adelheid throughout the play seems to know nothing about Weislingen's attachment to Maria; her rival is Goetz, not Maria. If our theory is correct, if Goethe consciously or unconsciously developed the Weislingen plot out of material gotten from Lillo's tragedy, we should have in a way an explanation for Adelheid's ignorance of Weislingen's first love. In the scene between Barnwell and Millwood we hear only of the merchant, but not of Maria, the merchant's daughter. This is perfectly natural, as Barnwell himself at this time is not aware of Maria's love for him. Adelheid appeals to Weislingen's sense of independence and self-respect that should keep him away from Goetz. "Geh und lass dich beherrschen .... . Du wirst ein Sclave eines Edelmannes werden, da du Herr von Fürsten seyn könntest" (D.j. G., II, 96). Millwood says to Barnwell: "I would have you shake off all slavish obedience to your master." It is not the accidental use of Sklave and "slavish" that forms the parallel, but the desire of both women to make the victims independent of their friends and benefactors-a step which will make them all the more dependent upon their fair seducers. There is, to be sure, an important difference also: Millwood wants Barnwell to remain in the service of Thorowgood, as that will enable him to supply her with money. Both men are reluctant to desert their benefactors. Barnwell, realizing his situation, says to himself: "I must be gone while I have power to go;" then, turning to Millwood: "Indeed, I must (leave you ) . . . . should I wrong him (my master) though he might forgive me, I never should forgive myself." Weislingen says to Adelheid (D. j. G., II, 95): "Ich muss (fort)! Zöge mich nicht die Ritterpflicht, der heilige Handschlag- .... Hättest du gefühlt wie liebreich er mir begegnete." Again the similarity of the situation is of importance, not the use of "I must go." Both men strongly feel the moral obligation to their benefactors. Millwood replies to Barnwell: "Am I refus'd, by the first man, the second favour I ever stoop'd to ask? go then thou proud hard-hearted youth-But know, you 
are the only man that cou'd be found, who wou'd let me sue twice for greater favours." Adelheid simply replies "So geht! (mit Verdruss)." The effect is the same; after a brief struggle both men stay. It is the beginning of their moral ruin. By staying they have become guilty of disloyalty, yes treachery; they are bound to sink deeper and deeper. Millwood's maid, Lucy, states this in an aside: "Lo! she has wheedled him out of his virtue of obedience already, and will strip him of all the rest, one after another, till she has left him as few as her ladyship, or myself." The words apply also to Weislingen; Adelheid gradually strips Weislingen of all the good qualities he may have had before. There is another slight similarity in the method pursued by the two women: they pretend to have a personal interest in their victims. Millwood says (p. 113): "the interest I have in all that relates to you." Adelheid expresses the same idea more cleverly (D. j. G., II, 96): "Ich redete für eure Freiheit-und weiss aberhaupt nicht was ich für ein Interesse dran nahm."

When Barnwell comes home after his first visit at Millwood's, his conscience is aroused (Act II, sc. 1): "How strange are all things round me! like some thief, who treads forbidden ground, and fain wou'd lurk unseen, fearful I enter each apartment of this well known house." Similarly, Weislingen, as soon as he has definitely decided to stay near Adelheid, is overcome for a moment by remorse and evil forebodings ( $D . j$. G., II, 97): "Auch ist mir's so unheimlich wohin ich trete. Es ist mir so bang als wenn ich von meinem Schutzgeiste verlassen, feindseligen Mächten überliefert wäre."

The two women are not content with having made traitors out of their lovers, they go farther. Barnwell is to attempt the life of his uncle, while Weislingen must hunt down and destroy his former friend and benefactor. Weislingen's reluctance to condemn Goetz (D.j. G., II, 178) arouses Adelheid's anger and contempt: "ihn selbst zu verdammen-hast du nicht das Herz . . . . Du bist von jeher der Elenden einer gewesen, die weder zum Bösen noch zum Guten einige Kraft haben." Franz is similarly treated. When he refuses to betray his master, Adelheid taunts him ( $D . j$. G., II, 169) : "Wo bist du dem Gewissen geschwind begegnet?" 
Millwood fails to understand how Barnwell, after actually murdering his uncle, should have lacked the heart to rob him. His qualms of conscience elicit the words: "It seems you are afraid of your own shadow; or what's less than a shadow, your conscience . . . . Whining, preposterous, canting villain" (Act IV, sc. 2).

When Millwood sees that Barnwell is of no more use to her, yes that he will involve her in his ruin, she quickly resolves to get rid of him (Act IV, sc. 2):

"In his madness he will discover all and involve me in his ruin; we are on a precipice from whence there's no retreat for both-then to preserve myself-there is no other way-' $t$ is dreadful-but reflection comes too late when danger's pressing-and there's no room for choice.-It must be done."

She then turns Barnwell over to the officers of the law. Adelheid only waits until Weislingen has signed Goetz's death warrant; then she poisons him, as he is in the way of her plans. The same fate overtakes Franz directly after the most passionate scene between him and Adelheid (D. $j$. G., II, 184 f.):

Ich habe mich hoch in's Meer gewagt, und der Sturm fängt an fürchterlich zu brausen. Zurück ist kein Weg. Weh! weh! Ich muss eins den Wellen Preis geben, um das andere zu retten. Die Leidenschaft dieses Knaben droht meinen Hoffnungen . . . . Du musst fort.

The words form the counterpart to Millwood's soliloquy: the same realization that the past cannot be undone, the same determination to take the next step required by the logic of events, the same apparent horror at the dreadfulness of the measure. The resourcefulness and determination of the two women come out strongly when apparently every escape is cut off. Millwood manages to find a pistol to protect herself (Act IV, sc. 2), while Adelheid just as unexpectedly draws a dagger from under her pillow (D. j. G., II, 195).

Even Millwood's end bears a certain resemblance to Adelheid's death, strange as it may seem at first sight. There were three solutions that most naturally presented themselves. Goethe might have made Adelheid commit suicide, like Cleopatra in Shakespeare's Antony and Cleopatra; or he might have allowed 
her to go off unmolested, but morally annihilated, as Lessing does with Marwood in Miss Sara Sampson; or he could bring her before a court of justice and have her sentenced for her crimes, as is Millwood's fate. Goethe chose the third solution: Adelheid is arraigned in court, sentenced, and executed before our eyes. To be sure the court and the circumstances attending Adelheid's execution are altogether different from anything found in Lillo's play.

Before being strangled by the murderer, Adelheid exclaims in despair (D. j. G., II, 195):

Mein Mass ist voll. Laster und Schande haben mich wie Flammen der Hölle mit teuflischen Armen umfasst. Ich büsse, büsse. Umsonst suchst du Laster mit Laster, Schande mit Schande zu tilgen. Die scheusslichste Entehrung und der schmählichste Tod in einem Höllenbild vor meinen Augen.

Millwood is also overcome by despair, as her end approaches (last scene) :

Is this the end of all my flattering hopes? were youth and beauty given me for a curse, and wisdom only to insure my ruin? they were, they were. Heaven, thou hast done thy worst, or if thou hast in store some untried plague, somewhat that's worse than shame, despair and death, unpitied death, confirmed despair and soul-confounding shame, .... now pour it now on this devoted head . . . . mercy's beyond my hope; almost beyond my wish. I can't repent nor ask to be forgiven.

After Millwood has been led away, Lucy describes the state of mind of her former mistress: "She goes to death encompassed with horror, loathing life, and yet afraid to die; no tongue can tell her anguish and despair." The lines may be applied word for word to Adelheid's state of mind.

There are other points in which Adelheid resembles Millwood. Adelheid's uncommon beauty and intelligence are the powerful weapons with which she conquers every man within her reach. Precisely the same qualities mark Millwood. Goethe reveals to us Adelheid's powers in the actions of the characters, Lillo again has to resort to words. Moreover, Lillo's intention is not to portray human passions, but to preach morality. Barnwell is the only man we see in Millwood's power, but we are told that no man is able to resist her. The old merchant Thorowgood, when 
he sees Millwood in her apartment, exclaims (Act IV, sc. 2): "The powerful magick of her wit and form might betray the wisest to simple dotage, and fire the blood that age had froze long since." He calls her sorceress, as Weislingen calls Adelheid Zauberin (D.j.G., II, 102). Again the parallel is not the use of the same word, but the fact that these women seem to possess almost supernatural powers. Later Thorowgood exclaims: "What pity it is, a mind so comprehensive, daring and inquisitive shou'd be a stranger to religion's sweet and powerful charms!" Even Lucy admires the "wit and beauty" of her mistress (Act I, sc. 2). The contrast between Adelheid's exterior and her black soul is forcibly brought out by the exclamation of the murderer (D.j.G., II, 192): "Gott! machtest du sie so schön, und konntest du sie nicht gut machen!" ' Thorowgood, less forcibly, says to Millwood $(\mathrm{IV}, 2)$ : "the abuse of such uncommon perfections of mind and body is not the least (of your faults)."

A few other scenes must be mentioned where under the surface certain striking parallels may be detected. One of the most pathetic scenes in Goetz is Maria's visit to Weislingen, when he is in the agonies of death. The technical reason for the visit is Maria's desire to obtain Goetz's pardon; the real reason, however, is doubtless the great dramatic possibility of a scene in which the discarded sweetheart faces her disloyal lover, who has met with just retribution. In Lillo's play we have a somewhat similar situation, when Maria visits Barnwell, who is in the despair of death-a scene which is not without power in spite of several false touches. To be sure, Maria has not been deserted by Barnwell in the same manner in which Goetz's sister has been deserted by Weislingen. Just before Maria enters, Barnwell says to himself, "I now am what I've made myself." Weislingen says to Maria (D. $j$. G., II, 188): "Ich bin meinen eigenen Weg gegangen, den Weg zum Verderben." Both men ask their visitors to pray for them. Maria's love makes Barnwell's sufferings all the greater. "This is indeed the bitterness of death," he says to himself (p. 179). He implores Maria to leave

1 The remark of the murderer throws an interesting light upon Goethe's attitude toward personal responsiblity during his Storm and Stress period; God has made man, and is responsible for the good and evil within man. 
him: "fly, abhor and leave me to my fate." Trueman feels that Maria's presence can only aggravate his woes; but Maria, overcome by her grief, confesses to Barnwell her love. For Weislingen, too, the presence of Maria is only an aggravation of his sufferings; he begs Maria to leave him, but Maria stays; she remembers how strongly she once loved him, yes we feel she still loves him, but as Sickingen's wife she must not talk to him of love (D.j. G., II, 186).

"Du Engel des Himmels bringst die Qualen der Hölle mit dir." Maria (p. 187): "Sein Anblick zerreisst mir das Herz. Wie liebt ich ihn! Und wie ich sein Angesicht sehe fühl ich wie lebhaft. Er hatte meine ganze Liebe, er hat mein volles Mitleiden." Weislingen (p. 189): "Geh aus der Nachbarschaft dieser Hölle .... Ich bitte dich geh . . . . Und den letzten einzigen Trost, Maria, deine Gegenwart - Ich muss dich weg bitten-Das ist mehr Qual als alles. Du Seele voll Liebe! bete für mich! bete für mich! . . . . Sogar ich fühle nur Elend in deiner Liebe.

The overwhelming power of Barnwell's passion we see from his remark to Trueman $(\mathrm{V}, 1)$ : "I was so devoted to the author of my ruin that had she insisted on my murdering thee,-I think -I should have done it." To retain Millwood's favor he actually murders his uncle who, he says, has been a father to him (III, 3). We are reminded of Franz's love-frenzy and his startling exclamation (D.j. G., II, 185): "Ich wollte meinen Vater ermorden, wenn er mir diesen Platz streitig machte." Are these mad words a lingering echo of Barnwell's murder of his uncle who had been a father to him?

Whatever value may be placed upon some of the parallels, taken as a whole they seem to me to prove conclusively that Lillo's play exercised considerable influence upon the conception of the characters and of some of the scenes in the Weislingen plot of Goetz von Berlichingen. Weissenfels has given us an excellent account of the origins of Goethe's drama, how the poet combined into an organic whole the tendencies of his time, literary traditions, and his personal views and experiences, and put upon it the stamp of his own genius. But while he mentions Lessing's Miss Sara Sampson and emphasizes the influence of Shakespeare's Antony and Cleopatra, as Minor and Sauer had 
done in their Goethe-Studien, he omits altogether Lillo's play. And yet the History of George Barnwell has the same claim to a place among the literary ancestors of Goetz von Berlichingen as Shakespeare's Antony and Cleopatra. ${ }^{1}$

The importance of Millwood's character for the Storm and Stress period deserves a few additional remarks. Minor states indeed (Schiller, Vol. II, p. 121) that Lillo's drama is the startingpoint for that type of feminine characters that finds its strongest expression in women like Marwood, Orsina, Lady Milford-a type that exercised so strange a fascination upon the German poets of the second half of the eighteenth century. But Millwood also anticipates sentiments that are characteristic of the Storm and Stress. "I follow'd my inclinations, and that the best of you do every day," she says to Thorowgood (Act. IV, sc. 2). "All actions seem alike natural and indifferent to man and beast." Her contempt for the clergy is complete.

In pride, contention, avarice, cruelty and revenge, the reverend priesthood were my unerring guides. . . . . I am not fool enough to be an atheist! . . . Whatever religion is in itself, as practis'd by mankind, it has caused the evils you say it was design'd to cure.

Karl Moor expresses similar views, when he says (Räuber, II, 3):

Was ich gethan habe, werde ich ohne Zweifel einmal im Schuldbuch des Himmels lesen; aber mit seinen erbärmlichen Verwesern will ich kein Wort mehr verlieren.

Karl Moor's contempt of human law, to which he gives forceful utterance in several places, is shared by Millwood (IV, 2):

What are your laws, of which you make your boast, but the fool's wisdom, and the coward's valour? the instrument and screen of all your villainies; by which you punish in others what you act yourselves; or wou'd have acted, had you been in their circumstances. The judge, who condemns a poor man for being a thief, had been a thief himself had he been poor.

1 Some of Goethe's contemporaries seem to have recognized at once a relationship between Goetz and Lillo's play. I infer that from a review of Chn. H. Schmid's treatise, Uber Gotz von Berlichingen: Eine dramaturgische Abhandlung (1774), which appeared in Nicolai's Allgemeine Deutsche Bibliothek and is reprinted in Braun, Goethe im Urteil seiner Zeitgenossen, pp. $336 \mathrm{ff}$. The reviewer says: "Die Scene des heimlichen Gerichts in Gotz finden wir recht gut; aber warum soll nun gleich Otway, Shakespear und Lillo das entgelten?" The writer also compares Adelheid and Millwood. Sichmid's treatise is not accessible to me. 
Millwood's hatred and contempt of men come out in her conversation with Trueman:

That imaginary being [i. e., the devil] is an emblem of thy cursed sex collected. A mirror, wherein each particular man may see his own likeness, and that of all mankind. . . . . Well may I curse your barbarous sex.

Lenz's Donna Diana in Der neue Menoza is filled with the same hatred:

Lass uns Hosen anziehen, und die Männer bei ihren Haaren im Blute herumschleppen . . . . die Hunde, die uns die Hände lecken, und im Schlafe an der Gurgel packen (Act II, sc. 3; cf. also III, 2, 8).

HaRvard University.

John A. WALz. 